\title{
\begin{tabular}{ll}
\hline 論 説 \\
\hline
\end{tabular} \\ トレンチ調査に基づく柳ヶ瀬-養老断層系, 鍛治屋断層の活動履歴
}

\author{
産業技術総合研究所活断層 ・ 火山研究部門* 吉 岡 敏 和 \\ 株式会社ダイヤコンサルタント** 佐 護 浩 一
}

\section{Paleoseismology of the Kajiya Fault in the Yanagase-Yoro Fault System, Cental Japan, Revealed by a Trench Excavation Study}

\author{
Toshikazu YosHiokA \\ Research Institute of Earthquake and Volcano Geology, \\ National Institute of Advanced Industrial Science and Technology \\ Site 7, 1-1-1 Higashi, Tsukuba 305-8567, Japan \\ Koichi Sago \\ Dia Consultants Co. Ltd. \\ 2-272-3 Yoshino-cho, Kita-ku, Saitama 331-0811, Japan
}

(Received February 17, 2015; Accepted June 26, 2015; published online on July 21, 2015)

The Yanagase-Yoro fault system extends from Japan Sea to Ise Bay, central Japan, in a NNW-SSE direction with a left-lateral strike-slip component of displacement. We carried out geomorphological and geological surveys on the Kajiya fault in the fault system to reveal its paleoseismic activities. Two trenches at sites $\mathrm{A}$ on the upper terrace and one trench at site B on the lower terrace were excavated. A high-angle fault cutting terrace deposits and black soil layers was exposed on the trench walls at site A. At site B, a fault was observed to cut bedrock and terrace deposits. These trench surveys and radiocarbon dates reveal that the latest faulting event on the Kajiya fault occurred after 1034 AD. This faulting event may be correlated to the 1325 AD Shochu earthquake or the 1586 AD Tensho earthquake. The penultimate and antepenultimate events seem to have occurred in about 3,000-3,500 years ago and about 7,000 years ago. The vertical slip-rate at site $\mathrm{B}$ is estimated to be 0.3 to $0.4 \mathrm{~m} / \mathrm{ky}$ from the correlation of terrace gravels between the bore-hole core and the trench wall.

Key words: Kajiya fault, Yanagase-Yoro fault system, Active fault, Paleoseismology, Trench excavation

\section{§1. はじめに}

柳ヶ瀬-養老断層系 [杉山・他 (1994)］は，福井県若狭 湾東岸から，近江盆地の北東縁，伊吹山の南麓から養老 山地の東縁を経て，伊勢湾の西岸に至る全長約 $140 \mathrm{~km}$ に及ぶ活断層系である (Fig. 1). 断層系全体の走向は概 ね北北西一南南東ないしは北西-南東方向であり, 左横ず れ変位を伴っているが, 北部では東側隆起, 南部では西

* =305-8567 つくば市東 1-1-1 中央第 7

** テ331-0811 さいたま市北区吉野町 2-272-3
側隆起の逆断層変位が卓越する[活断層研究会編 (1991), 岡田・東郷編 (2000)など]. 本断層系の過去の活 動時期については, 北部の柳ヶ瀬断層では, 椿坂地点で 西暦 1200 年代後半 1400 年代初頭に [杉山・他 (1993)], その北の椿坂峠地点では約 7,000 7,200 年前に [吉岡・ 他 (1998)]，それぞれ最新活動があったという結果が得 られている。一方, 南部の養老断層では, 最新活動は 14 世紀以降に，それに先立つ活動は 7〜9世紀にあったと されている [須貝・他 (1999)]。 また南部の桑名断層で 


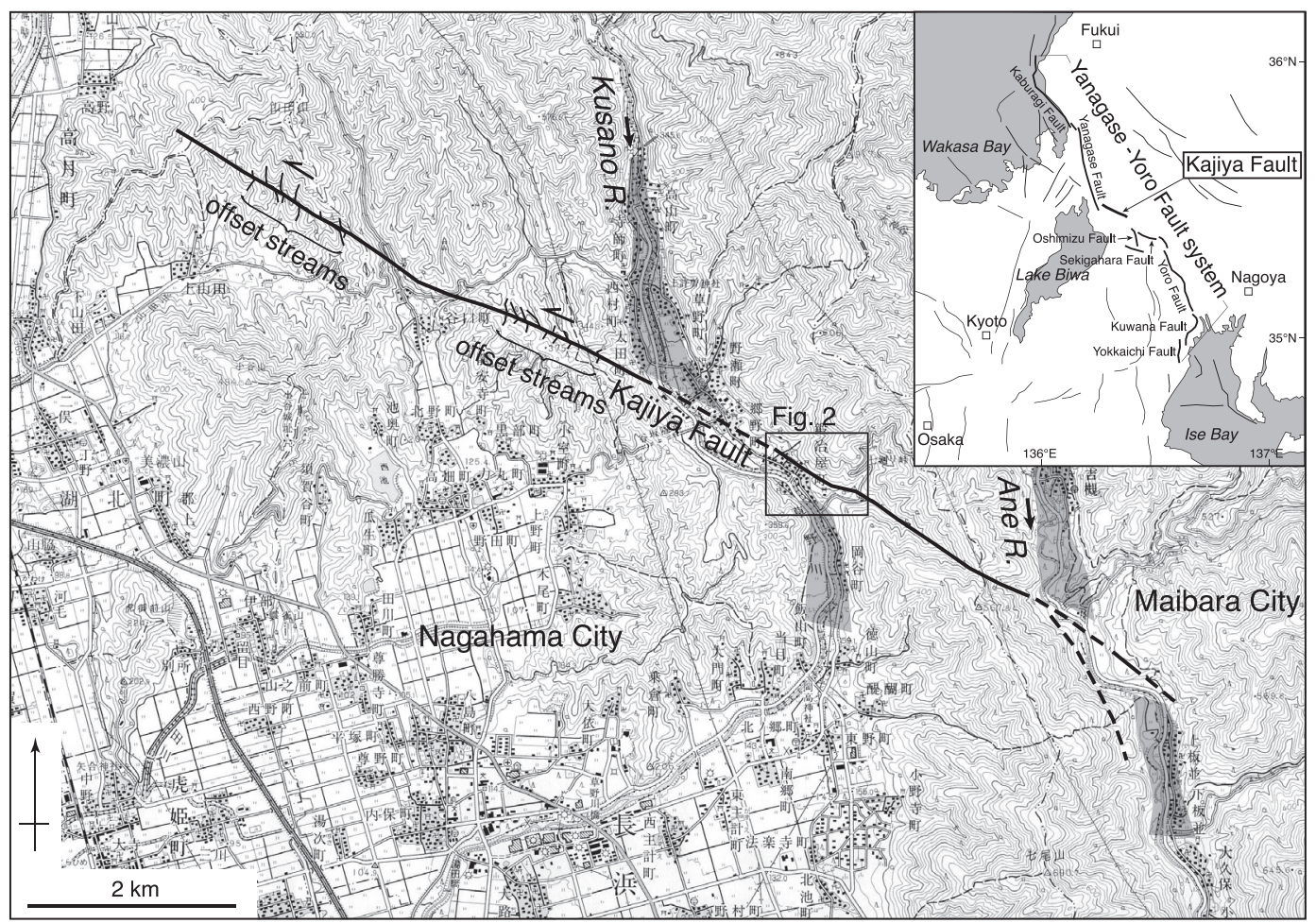

Fig. 1. Location of the Yanagase-Yoro fault system and the Kajiya fault. Topographic map "Nagahama" at a scale of 1:50000 issued by Geospatial Information Authority of Japan is used. Shadowed parts are offset valleys. Thin lines in index map are other major active faults.

は, 最新活動は 13 世紀以降に，それに先立つ活動は 6〜10 世紀にあったとされている[須貝・他 (1998)]。 し かしながら，断層系の中部にあたる鍛治屋断層，大清水 断層，関ヶ原断層等の活動履歴については，これまでに 具体的なデー夕は得られていなかった．柳ヶ瀬一養老断 層系のような長大な断層系における個々の活断層の活動 履歴を詳細に明らかにすることは，その地域における将 来の地震発生予測のみでなく，断層系を構成する各断層 の連動性を評価する上でも重要なデータとなることが期 待される.

本研究は, 平成 22 年度文部科学省委託事業「活断層の 追加・補完調査」として実施した調査に基づき，柳ヶ瀬 一養老断層系のうちの鍛治屋断層の活動性および活動履 歴を明らかにすることを目的に，その後の調査研究を加 えたものである。本稿の内容の一部は速報として吉岡・ 他 (2011) で発表されているが, 本稿は, そのトレンチ壁 面の解釈を再検討するとともに，考察を追加したもので ある。

\section{$\S 2 . \quad$ 調査地点の変位地形と調査内容}

鍛治屋断層は，琵琶湖の北東，滋賀県長浜市小谷上山 田北方の山田山南麓から同市鍛治屋町付近を通って米原
市上板並付近まで, 北西-南東方向に延びる全長約 11 $\mathrm{km}$ の左横ずれ活断層である (Fig. 1)，断層周辺は標高 600 1,000 m 程度の山地で, 美濃帯に属する中生界の堆 積岩類からなる。断層を横切って草野川および姉川が北 から南に流れており, 草野川の河谷は断層を横切る地点 において $1.5 \sim 2 \mathrm{~km}$ 程度, 姉川の河谷は $500 \mathrm{~m} \sim 1 \mathrm{~km}$ 程 度，それぞれ左屈曲している。

断層に沿っては，北西部の山間部において小規模な河 谷の系統的な左屈曲が認められる[杉山・他 (1994), 東 郷・他 (2005)]。屈曲量は数十 $\mathrm{m}$ 程度である。断層の中 央部分は草野川の河谷と一致するため, 顕著な変位地形 は認められない。段丘面の分布は局所的で，草野川およ び姉川沿いにわずかに認められるのみである。

断層のほぼ中央部にあたる長浜市鍛治屋町付近の 1961 年撮影の空中写真を Fig. 2 に示す。この地域には, 草野川左岸の山麓部に上下 2 面の段丘（高位から I 面お よびII 面とする）が分布しており，沖積面からの比高は I 面で約 $30 \mathrm{~m}$ ， II 面で約 $10 \mathrm{~m}$ である。このうち I 面は, 支流からの扇状地によって形成されたと推定され，石村 (2010) の M2 面（50-70 ka と推定）に相当する. II 面は 草野川本流によって形成されたと推定され, 形成年代に ついては具体的なデー夕は得られていないが, 沖積面か 

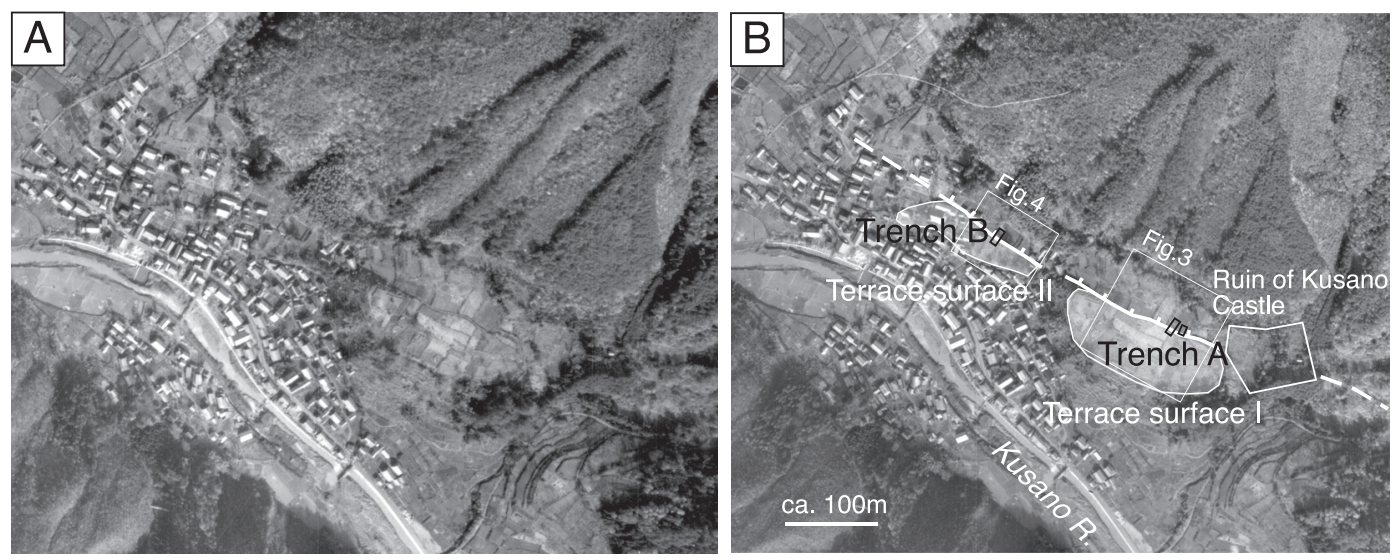

Fig. 2. Stereoscopic airphotographs taken by Geospatial Information Authority of Japan in 1961

(KK-61-10 C6B-12, 13). Interpreted topographic features are added in B.

らの相対的な比高から最終氷期に形成された可能性が高 いと考えられる．Ｉ面上の一部は，中世に城郭（草野城） として利用され，一部に堀の跡等の人工的な地形が見ら れるが，その西に隣接する一带はほぼ自然の地形が残存 している。近世以降，I面上は昭和 40 年頃まで農地とし て，II 面は宅地として利用されていたため，人為的に地 形が改変されているものの, いずれの面上にも地形とは 逆に北東側が低下する直線的な崖地形が認められ，鍛冶 屋断層の低断層崖と考えられる。崖の比高は，I面では 約 1.5-2 m, II 面では約 $0.5 \mathrm{~m}$ である。なお，この崖地形 は空中写真から推定される草野城の範囲では認められな い.

調査は, これらの逆向き低断層崖を横切るように, I 面上 (A 地点) に扔いて2 溝のトレンチを, II 面上 (B 地 点）において1溝のトレンチと 1 孔のボーリングを掘削 した，両地点間の距離は約 $200 \mathrm{~m}$ である。そそれ゙れの 地点の実測平面図を Fig. 3 抢よび Fig. 4 に示す.

\section{$\S 3 . \quad$ 調 查結果}

\section{$3.1 \quad$ Al トレンチ}

A1 トレンチ壁面のスケッチを Fig. 5 に示す。壁面に は，段丘堆積物とその上位の黑色土壤，およびそれらを 変位させる断層が露出した，壁面に露出した地層を，上 位から 1 層〜 5 層に区分した。 1 層は人工改変を受けた 表土, 2 層はやや不淘汰な碩混じり黒色腐植土層である. なお， 1 層と 2 層の境界の位置は, 吉岡・他 (2011) を見 直し，一部修正している． 3 層は角䂰混じりの黒色の腐 植質土壤で, 色調や礫の含有率により $3 \mathrm{a}$ 層から $3 \mathrm{e}$ 層に 細分した. 3a 層は比較的磼が少なめの黒色の腐植土層, $3 \mathrm{~b}$ 層はやや暗褐色のシルト質腐植土層で, 西壁面では 長径 $30 \mathrm{~cm}$ 程度の硆を含む. $3 \mathrm{c}$ 層は $3 \mathrm{a}$ 層と類似する黒
色の腐植土層， $3 \mathrm{~d}$ 層は暗褐色の砂混じり腐植土層， $3 \mathrm{e}$ 層は比較的磉を多く含む暗褐色ないし黒色の腐植土層で

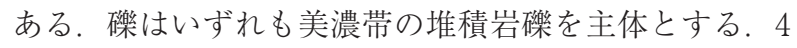
層は断層沿いに挟まれるように分布する角䃋層で，磁は 5 層と類似するがマトリクスが粘土質である，5層は角

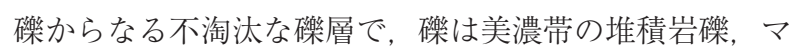
トリクスは黄褐色のシルトを主体とする．5層はその分 布から I 面を構成する段丘堆積物であると考えられる。

壁面に露出した断層はほぼ垂直で, 大局的には段丘堆 積物である 5 層と腐植質の土壤の 3 層の境界をなしてい る, そのうち最も顕著な断層は, 東壁面では 4 層の内 部, 西壁面では 4 層と $3 \mathrm{~d}$ 層の境界をなす断層で, これ を主断層とする。この主断層以外に, 3 層内部には数条 の副断層が認められる，4層と5層の境界，および東壁 面の $3 \mathrm{c}$ 層, $3 \mathrm{e}$ 層と 4 層の境界は, 物質境界としては明 瞭であるが, 不規則に湾曲して抢り，境界面には顕著な すべり面は観察されない.

副断層のうち, 東壁面の最も北側の断層は $3 \mathrm{a}$ 層上部 までを変位させているが，いずれの副断層も2 層は変位 させていないことから，3a 層堆積後，2 層堆積前に副断 層の活動があったと考えられる。な㧍主断層は 1 層のみ に覆われ，2 層との関係は不明である。西壁面では，3d 層の上面が断層から北に向かって $45^{\circ}$ 程度の傾斜で傾き 下がって抢り，上位の $3 \mathrm{c}$ 層はその斜面を覆うように低 下側にやや厚く堆積している，3d 層は，3層の他の部分 より色調が淡く，断層に向かって厚くなる楔形に堆積し ていることから，断層隆起側の 5 層から供給されたと考 えるのが合理的である。したがって, $3 \mathrm{~d}$ 層は, 断層活動 で南側が隆起するのに伴い, その際に形成された低断層 崖の基部に堆積したイベント堆積物である可能性が指摘 できる。な扮，東壁面では，グリッド $\mathrm{E} 2 ， \mathrm{E} 3$ 間に扔い 

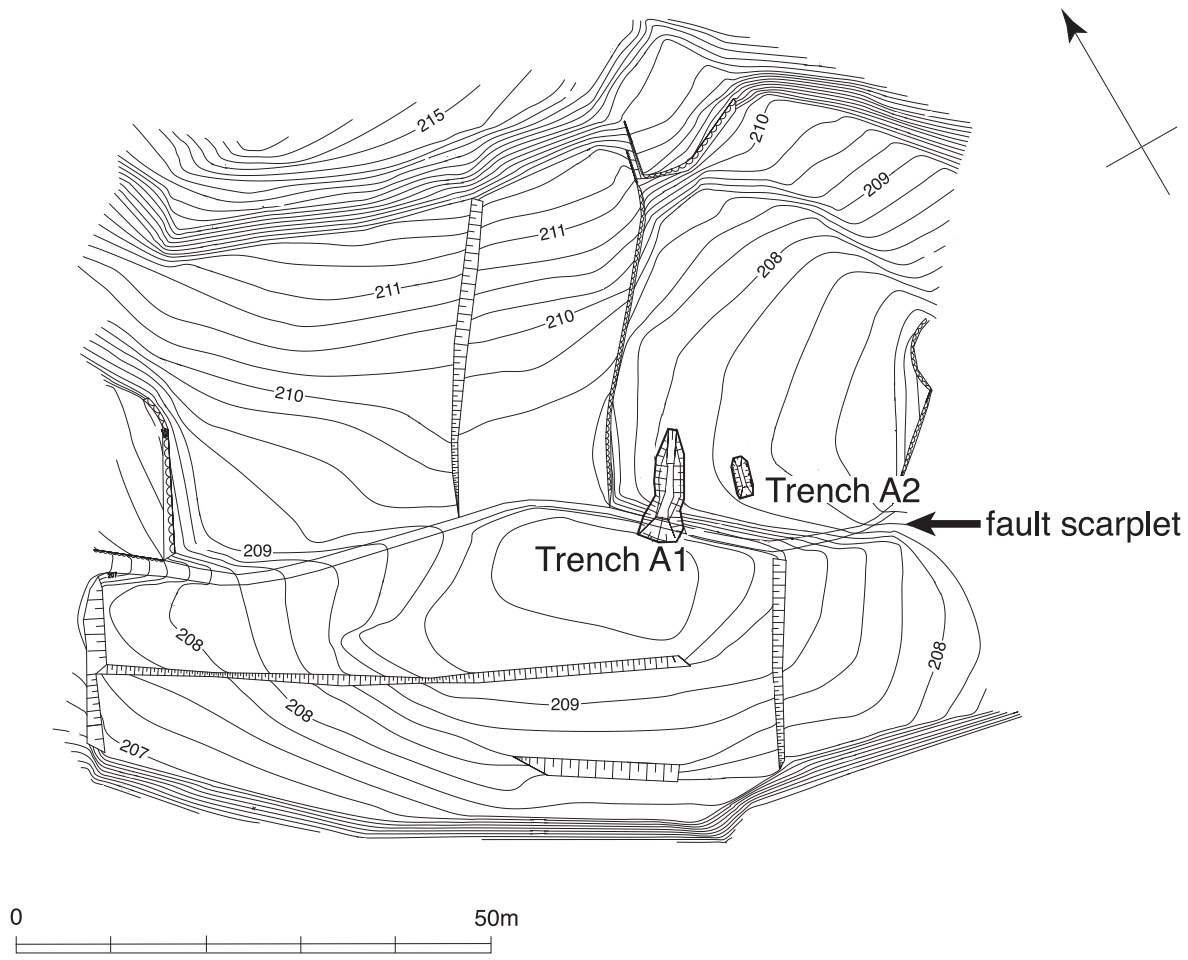

Fig. 3. Detail topographic map of the site A. Contour interval is $25 \mathrm{~cm}$.

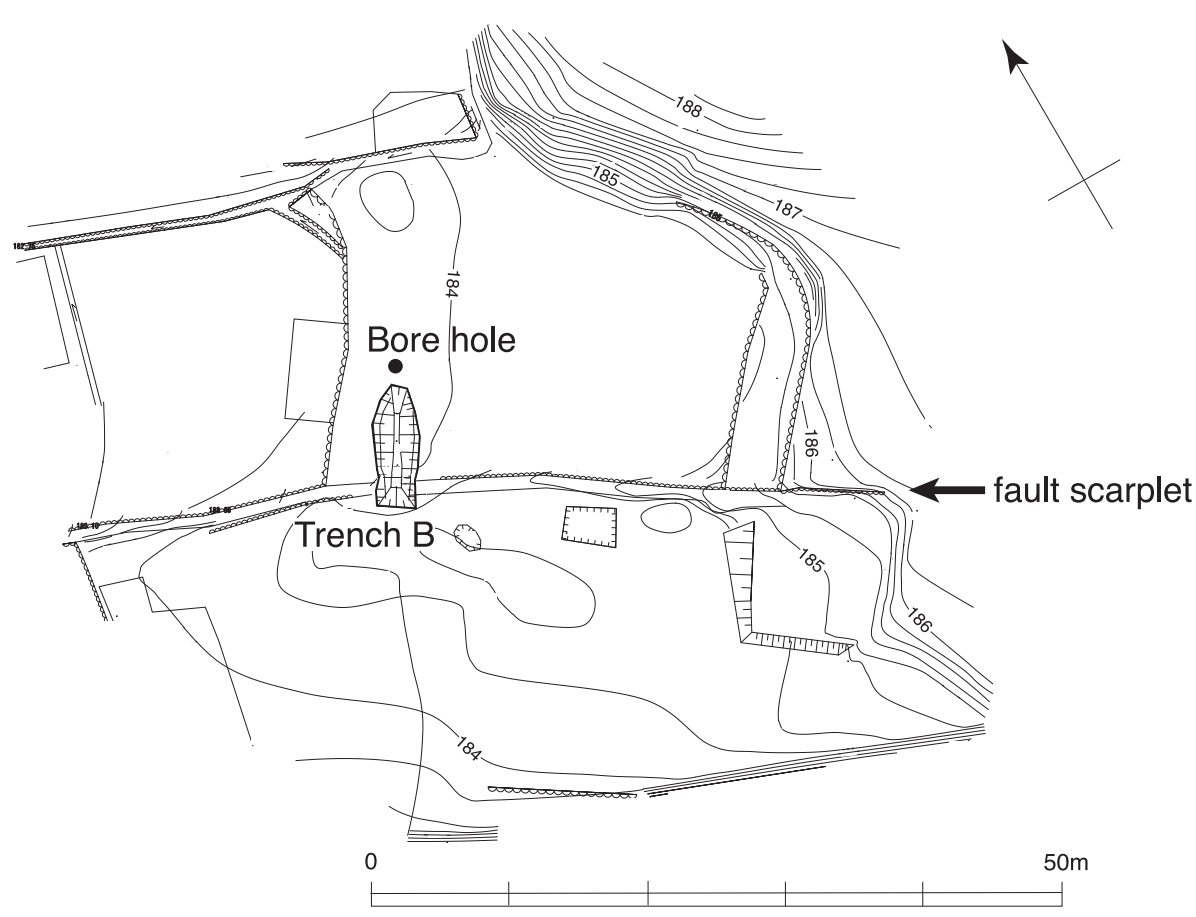

Fig. 4. Detail topographic map of the site B. Contour interval is $25 \mathrm{~cm}$.

て，3c 層が $3 \mathrm{e}$ 層に楔状に落ち込んでいるのに対し，3b 層と $3 \mathrm{c}$ 層の境界は大きく変形していない. しかしなが ら, 本断層は横ずれ変位を伴っているため, この落ち込
みは見かけの上下変位の可能性があり, $3 \mathrm{~b}$ 層堆積後の 断層活動によって形成された可能性を否定できない.

壁面から得られた試料の放射性炭素同位体年代測定の 


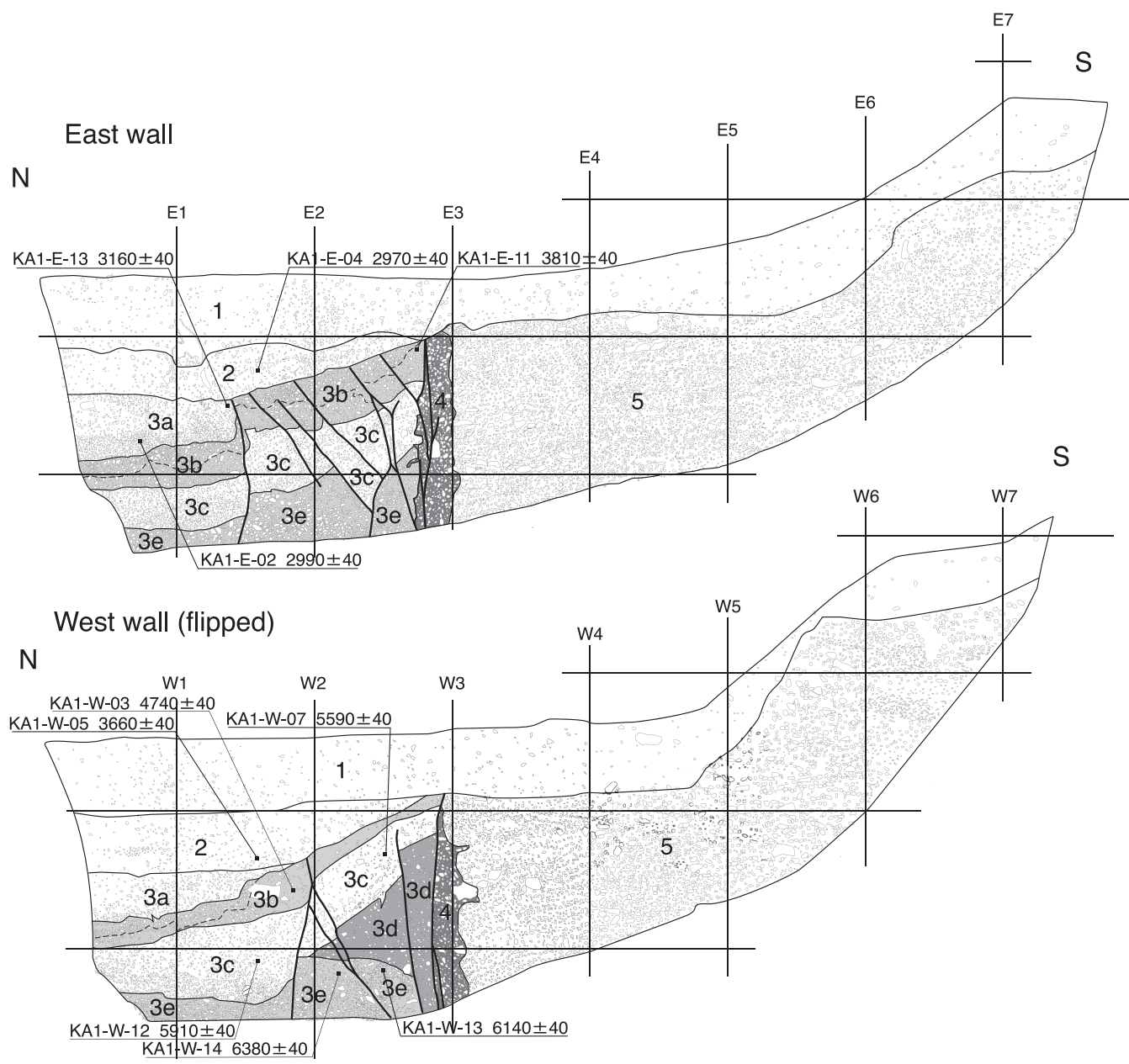

Fig. 5. Log of the Kajiya A1 trench. West wall is flipped. Grid interval is 1 meter on vertical plane. Thick solid lines are faults and thin solid lines are boundaries of sedimentary units. See Table 1 for more information about radiocarbon dates.

結果を Fig. 5 および Table 1 に示す. 以下本文では, デ ルタ ${ }^{13} \mathrm{C}$ 補正を行った ${ }^{14} \mathrm{C}$ 年代と暦年較正值（誤差幅 $2 \sigma$ ) を示す。暦年較正は, Oxcal 4.2 [Bronk Ramsey (2001), Bronk Ramsey and Lee (2013)] を使用し, IntCal 13 デー タセット [Reimer et al. (2013)] に基づいて計算した。副 断層を覆う 2 層の炭化物 (KA1-E-04) からは2970 yBP（暦年で BC 1371-1051 年), 有機質堆積物 (KA1-W05) からは 3660土40yBP (暦年で BC 2190-1926 年) の年 代值が得られた。しかしながら，KA1-W-05 から得られ た年代值は下位の $3 \mathrm{a}$ 層から得られた年代值よりも古い ため，下位層起源の土壌が再堆積したものと考えた．副 断層によって変位を受けた $3 \mathrm{a}$ 層の炭化物 (KA1-E-02) か らは 2990 土40yBP (暦年で BC 1386-1059 年), 有機質堆 積物 (KA1-E-13) からは 3160土40yBP（暦年で BC 15111303 年) の年代值が得られた。ささらに, 3c 層の有機質堆 積物 (KA1-W-07, KA1-W-12) からは5590土40yBP およ び 5910土40yBP（暦年で BC 4494-4350 年おょび BC
4897-4705 年), 3e 層の有機質堆積物 (KA1-W-13, KA1W-14) からは $6140 \pm 40 y B P$ および $6380 \pm 40 y B P （$ 暦年 で BC 5215-4981 年および BC 5471-5304 年) の年代值が 得られた。

\subsection{A2 トレンチ}

A1 トレンチでは, 地表面近くが人工改変を受け, 低 断層崖が後退していたために，断層の上端部と表層の土 壤との関係が十分に観察できなかった。そこで，A1 ト レンチに露出した断層の走向延長上にあり, 地形から堆 積物がより厚く堆積していると推定された地点におい て，やや規模の小さい A2 トレンチを掘削した.

A2 トレンチ壁面のスケッチを Fig. 6 に示す，壁面に は，A1 トレンチの 1 層から 3 層および 5 層に相当する 地層が露出したが， 3 層は細分することができなかった． 断層は, 西壁面では 3 層と 5 層の境界をなす主断層と 3 層中の副断層が, 東壁面では 3 層と 5 層の境界を階段状 に変位させる複数の断層が, それぞれ観察された。な 
Table 1. Radiocarbon dates of the samples. ${ }^{14} \mathrm{C}$ ages were corrected by $\delta^{13} \mathrm{C}$ and calculated using Libby half-life of 5568 years. Calendar years are dendrochronologically calibrated probable age ranges of confidence levels $95 \%$ (2б), using Oxcal 4.2 [Bronk Ramsey (2001), Bronk Ramey and Lee (2013)] and IntCal13 Radiocarbon Age Calibration database [Reimer et al. (2013)].

A1 trench

\begin{tabular}{|c|c|c|c|c|c|c|c|}
\hline $\begin{array}{c}\text { sample } \\
\text { no. }\end{array}$ & unit & sample & lab. no. & $\begin{array}{c}\text { delta }{ }^{13} \mathrm{C} \\
\text { calibrated age } \\
\text { (yBP) }\end{array}$ & $\begin{array}{c}\text { calendar year } \\
\text { (IntCal13) } \\
2 \text { Sigma }\end{array}$ & $\begin{array}{l}\text { dating } \\
\text { method }\end{array}$ & $\begin{array}{c}\text { pre- } \\
\text { treatment }\end{array}$ \\
\hline KA1-E-04 & 2 & charred material & Beta-288989 & $2970 \pm 40$ & BC 1371 to 1051 & AMS & AAA \\
\hline KA1-E-02 & $3 a$ & charred material & Beta-288993 & $2990 \pm 40$ & BC 1386 to 1059 & AMS & AAA \\
\hline KA1-E-13 & $3 a$ & organic sediment & Beta-289004 & $3160 \pm 40$ & BC 1511 to 1303 & AMS & A \\
\hline KA1-E-11 & $3 b$ & organic sediment & Beta-289002 & $3810 \pm 40$ & BC 2456 to 2137 & AMS & $\mathrm{A}$ \\
\hline KA1-W-05 & 2 & organic sediment & Beta-289001 & $3660 \pm 40$ & BC 2190 to 1926 & AMS & $\mathrm{A}$ \\
\hline KA1-W-03 & $3 b$ & charred material & Beta-288992 & $4740 \pm 40$ & BC 3638 to 3377 & AMS & AAA \\
\hline KA1-W-07 & $3 \mathrm{c}$ & organic sediment & Beta-289005 & $5590 \pm 40$ & BC 4494 to 4350 & AMS & $\mathrm{A}$ \\
\hline KA1-W-12 & $3 c$ & organic sediment & Beta-291058 & $5910 \pm 40$ & BC 4897 to 4705 & AMS & $\mathrm{A}$ \\
\hline KA1-W-13 & $3 e$ & organic sediment & Beta-289003 & $6140 \pm 40$ & BC 5215 to 4981 & AMS & $\mathrm{A}$ \\
\hline KA1-W-14 & $3 e$ & organic sediment & Beta-289000 & $6380 \pm 40$ & BC 5471 to 5304 & AMS & $\mathrm{A}$ \\
\hline
\end{tabular}

A2 trench

\begin{tabular}{cccccccc}
\hline $\begin{array}{c}\text { sample } \\
\text { no. }\end{array}$ & unit & sample & lab. no. & $\begin{array}{c}\text { delta }{ }^{13} \mathrm{C} \\
\text { calibrated age } \\
\text { (yBP) }\end{array}$ & $\begin{array}{c}\text { calendar year } \\
\text { (IntCal13) } \\
\text { 2 Sigma }\end{array}$ & $\begin{array}{c}\text { dating } \\
\text { method }\end{array}$ & $\begin{array}{c}\text { pre- } \\
\text { treatment }\end{array}$ \\
\hline KA2-E-07 & 2 & charred material & Beta-288991 & $2880 \pm 40$ & BC 1207 to 931 & AMS & AAA \\
KA2-E-13 & 3 & organic sediment & Beta-288988 & $5640 \pm 40$ & BC 4546 to 4366 & AMS & A \\
KA2-W-04 & 2 & organic sediment & Beta-288998 & $3850 \pm 40$ & BC 2461 to 2204 & AMS & AAA \\
KA2-W-01 & 3 & charred material & Beta-290273 & $3940 \pm 40$ & BC 2568 to 2299 & AMS & AAA \\
KA2-W-02 & 3 & organic sediment & Beta-288999 & $4900 \pm 40$ & BC 3768 to 3638 & AMS & A \\
\hline
\end{tabular}

B trench

\begin{tabular}{|c|c|c|c|c|c|c|c|}
\hline $\begin{array}{c}\text { sample } \\
\text { no. }\end{array}$ & unit & sample & lab. no. & $\begin{array}{c}\text { delta }{ }^{13} \mathrm{C} \\
\text { calibrated age } \\
\text { (yBP) }\end{array}$ & $\begin{array}{l}\text { calendar year } \\
\text { (IntCal13) } \\
2 \text { Sigma }\end{array}$ & $\begin{array}{l}\text { dating } \\
\text { method }\end{array}$ & $\begin{array}{c}\text { pre- } \\
\text { treatment }\end{array}$ \\
\hline KB-E-04 & $2 c$ & charred material & Beta-291063 & $230 \pm 40$ & AD 1521 to modern & AMS & AAA \\
\hline KB-E-11 & 3 & organic sediment & Beta-291061 & $1770 \pm 40$ & $\mathrm{AD} 135$ to 379 & AMS & A \\
\hline KB-E-05 & 4 & charred material & Beta-288990 & $890 \pm 40$ & AD 1034 to 1220 & AMS & AAA \\
\hline KB-E-01 & 4 & wood & IAAA-101489 & $1000 \pm 30$ & AD 983 to 1152 & AMS & AAA \\
\hline KB-E-10 & 4 & organic sediment & Beta-291060 & $1360 \pm 40$ & AD 607 to 766 & AMS & A \\
\hline KB-E-09 & 4 & organic sediment & Beta-288995 & $1640 \pm 40$ & AD 266 to 538 & AMS & $\mathrm{A}$ \\
\hline KB-E-07 & 5 & organic sediment & Beta-291059 & $3820 \pm 40$ & BC 2457 to 2142 & AMS & $\mathrm{A}$ \\
\hline KB-E-08 & 5 & organic sediment & Beta-288997 & $10280 \pm 50$ & BC 10429 to 9874 & AMS & $\mathrm{A}$ \\
\hline KB-W-02 & 3 & organic sediment & Beta-288996 & $2040 \pm 40$ & BC 167 to AD 51 & AMS & A \\
\hline KB-W-01 & 5 & organic sediment & IAAA-101490 & $10410 \pm 40$ & BC 10569 to 10137 & AMS & A \\
\hline \multicolumn{8}{|c|}{ borehole core in site B } \\
\hline $\begin{array}{c}\text { sample } \\
\text { no. }\end{array}$ & $\begin{array}{l}\text { deprh } \\
(\mathrm{m})\end{array}$ & sample & lab. no. & $\begin{array}{c}\text { delta }{ }^{13} \mathrm{C} \\
\text { calibrated age } \\
\text { (yBP) }\end{array}$ & $\begin{array}{c}\text { calendar year } \\
\text { (IntCall3) } \\
2 \text { Sigma }\end{array}$ & $\begin{array}{l}\text { dating } \\
\text { method }\end{array}$ & $\begin{array}{c}\text { pre- } \\
\text { treatment }\end{array}$ \\
\hline $\mathrm{K}-1-1$ & $.58-1.63$ & plant material & Beta-291062 & $1110 \pm 40$ & AD 778 to 1018 & AMS & AAA \\
\hline $\mathrm{K}-1-2$ & $.12-2.18$ & organic sediment & Beta-291064 & $6870 \pm 40$ & BC 5841 to 5670 & AMS & $\mathrm{A}$ \\
\hline $\mathrm{K}-1-3$ & 3.35 & organic sediment & Beta-291065 & $11250 \pm 50$ & BC 11276 to 11082 & AMS & A \\
\hline $\mathrm{K}-1-4$ & 4.90 & wood & Beta-292947 & $16090 \pm 70$ & BC 17670 to 17250 & AMS & AAA \\
\hline $\mathrm{K}-1-5$ & $5.90-6.93$ & plant material & Beta-292948 & $17850 \pm 80$ & BC 19925 to 19419 & AMS & AAA \\
\hline $\mathrm{K}-1-6$ & 8.43 & plant material & Beta-292949 & $18930 \pm 90$ & BC 21100 to 20570 & AMS & AAA \\
\hline
\end{tabular}


お，A1 トレンチで確認できなかった主断層と 2 層との 関係については，西壁面では 2 層の基底が主断層に沿っ

\section{East wall}

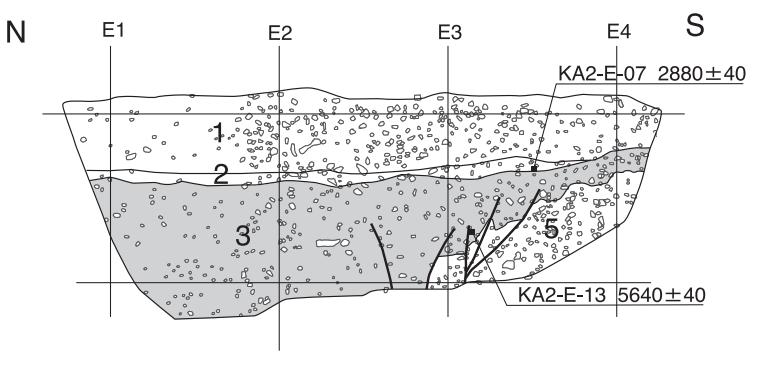

\section{West wall (flipped)}

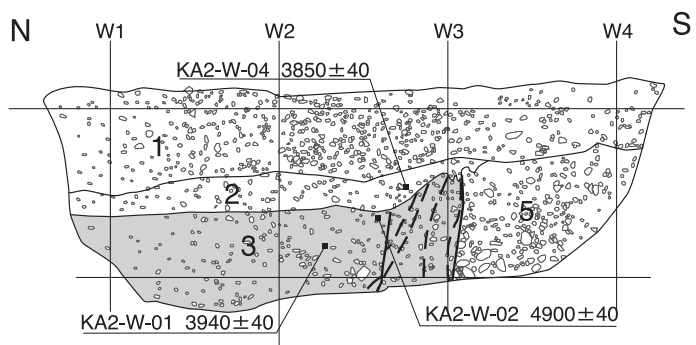

Fig. 6. Logs of the Kajiya A2 trench. Notes are the same as Fig. 5. Dashed thick lines are indistinct faults.
て落ち込むように分布しているものの，2 層内の構造が 不明瞭なため, 変形が 2 層に及んでいるかどうかは確認 できなかった。また東壁面においても，断層が上方に向 かってせん滅しているため, 2 層が変位を受けていない とは言い切れない。したがって，A2トレンチでは，断 層の活動時期について A 1 トレンチ以上の情報は得られ なかった。

\subsection{B トレンチ}

低位の段丘面上で掘削した B トレンチ壁面のスケッ チを Fig. 7 に示す。壁面では，南側に分布する基盤岩と その上位の段丘堆積物が, 北側に分布する細粒堆積物と ほぼ垂直な断層で接しているのが観察された。壁面に露 出した地層を, 上位から 1 層〜7層に区分した。このう ち, 1 層（1a 層, $1 \mathrm{~b}$ 層) は人工の盛土である，2 層は砂 混じり土壤であり, 層相からマトリクスが灰色のシルト からなる $2 \mathrm{a}$ 層, やや大きめの円礫を多く含む $2 \mathrm{~b}$ 層, マ トリクスが $2 \mathrm{a}$ 層に類似する $2 \mathrm{c}$ 層に細分した。いずれも 淘汰の悪い堆積物であること, 円礫が比較的多く含まれ ているものの, 地形からこの場所を流れる河川は想定し にくいことなどから，7層を削平した土砂で人為的に窪 みを埋めたものの可能性が高いと考えられる。3層は啋 混じりの腐植質シルト層, 4 層は未分解の植物遺体を多 く含む腐植土層である．5層は白色のシルトないし粘土
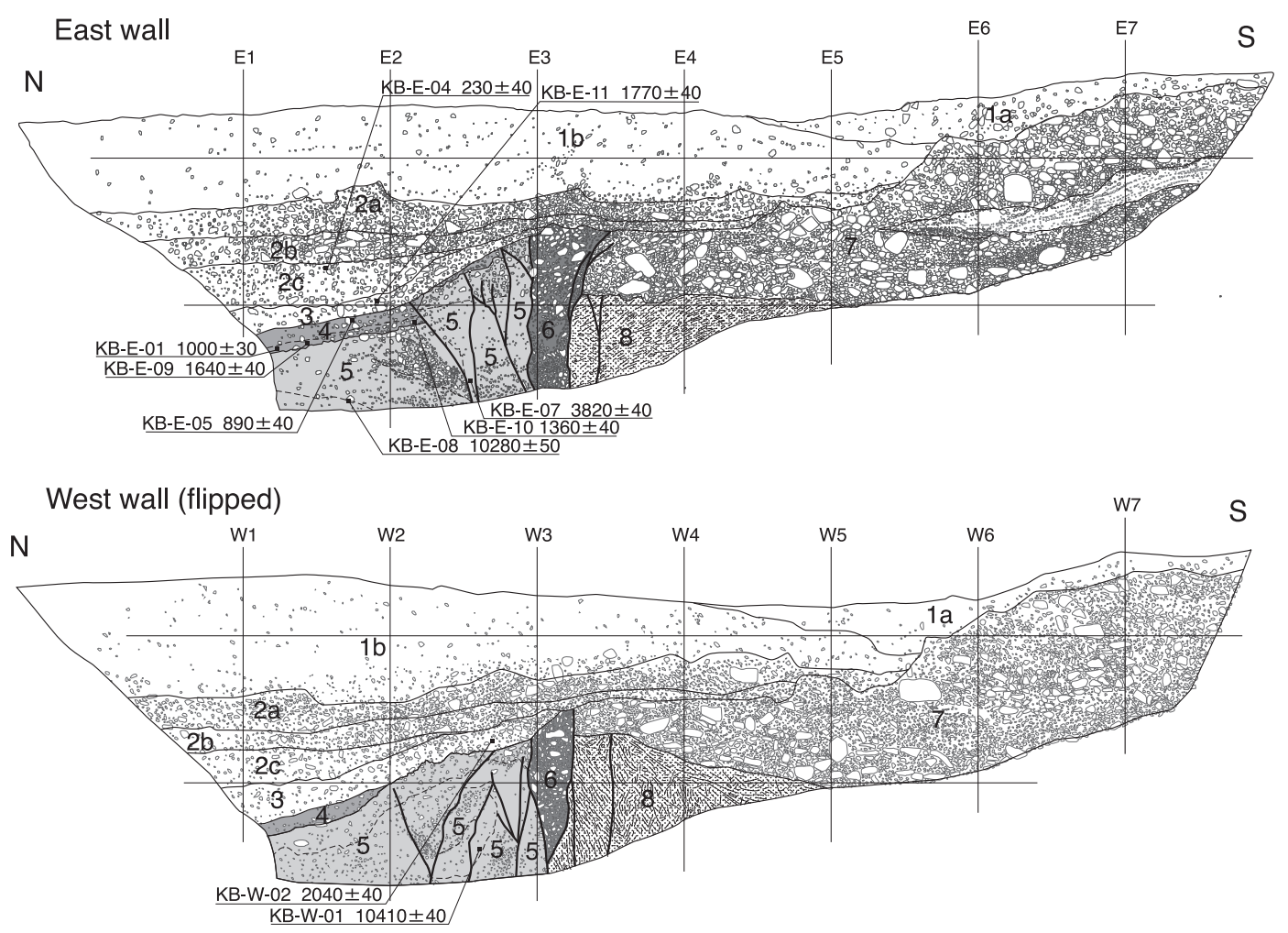

Fig. 7. Log of the Kajiya B trench. Notes are the same as Fig. 5. 
層を主体とし，円礫層およびやや腐植質のシルト層を挟 む. 6 層は断層に挟まれるように分布する円〜亜角礫層 で，マトリクスは粘土質である， 7 層は比較的淘汰のよ い円〜亜角礫層で，東壁面では厚さ $30 \mathrm{~cm}$ 程度の砂層を 挟む，基盤岩をほぼ水平に覆って分布していることか ら，草野川の本流による堆積物であり，II 面を構成する 段丘堆積物と考えられる。基盤岩は破砕した美濃帯堆積 岩類である。

断層は，6 層を挟んで基盤岩および 7 層と 5 層が接す る主断層と，数条の副断層からなる。低下側（北側）に 分岐するいくつかの断層は，東壁面で 4 層までを変位さ せ， 3 層に覆われるのが確認された。ささらに，5層中に挟 まれる礫層や腐植質シルト層が 4 層と比較してより大き く変形していることから, 5 層堆積後, 4 層堆積前にも断 層活動があったと推定される。

壁面から得られた試料の放射性炭素同位体年代測定の 結果を Fig. 7 および Table 1 に示す。断層変位を受けた 堆積物の最上位にあたる 4 層からは，890土40yBP〜 $1640 \pm 40 y B P$ の 4 つの年代值が得られた。そのうちの 最も新しい年代值は, KB-E-05の炭化物から得られた $890 \pm 40 \mathrm{yBP}$ （暦年で AD 1034-1220 年）である。した がって, この地点での鍛治屋断層の最新活動時期は $\mathrm{AD}$ 1034 年以後と推定される。断層を覆う 3 層の有機質堆 積物 (KB-E-11，KB-W-02) からは，4層から得られた年 代值より古い $1770 \pm 40 \mathrm{yBP}$ および $2040 \pm 40 \mathrm{yBP}$ （暦年 で $\mathrm{AD}$ 135-379 年および BC 167-AD 51 年）の年代值が 得られた。しかしながら，3 層は断層を覆う斜面に堆積 した地層であることから，断層活動前からすでに存在し ていた堆積物が, 断層活動後に再堆積したものの可能性 が高いと判断した。一方，東壁面の断層沿いの 5 層に挟 まれる有機質堆積物 (KB-E-07) からは 3820土40yBP（暦 年で BC 2457-2142 年) の年代值が得られたが，同じ 5 層の有機質堆積物 (KB-E-08, KB-W-01) からは 10280土 $50 \mathrm{yBP}$ および $10410 \pm 40 \mathrm{yBP}$ (暦年で BC 10429-9874 年 および BC 10569-10137 年) の年代值が得られた。

\subsection{B 地点ボーリング}

B トレンチでは，断層低下側の段丘堆積物および基盤 岩が確認できなかったため, トレンチの北端から約 1.5 $\mathrm{m}$ 北でボーリング調査を実施した (Fig. 4).コアの地層 は, 人工埋土の下, 地表から $1.78 \mathrm{~m}$ までが腐植質シルト 層（Bトレンチの 2〜4 層に対比)， $3.74 \mathrm{~m}$ までが腐植質 シルト層を挟むシルト質砂磁層（Bトレンチの 5 層に対 比），その下 $9.40 \mathrm{~m}$ までが亜角礫主体の砂礫層であり, 途中 8.34-8.81 $\mathrm{m}$ に円〜亜円礫層を挟む (Fig. 8). ボーリ ングは地表下 $9.4 \mathrm{~m}$ まで掘削したが，その深度では基盤 岩に達しないことが確認された。放射性炭素同位体年代
測定の結果, 深度 $8.43 \mathrm{~m}$ で礘層に含まれる植物遺体 (K1-6) からは $18930 \pm 90 \mathrm{yBP}$ (暦年で BC 21100-20570 年) の年代值が得られた (Table 1)。この礫層は円礫を含む こと，トレンチ壁面の 7 層で構成される段丘面 (II 面) が最終水期に形成されたと推定されることから，この礫 層はトレンチ壁面の 7 層と対比することができる.

\section{$\S 4$. 考 察 \\ 4.1 鍛冶屋断層の活動時期および活動間郚}

トレンチ壁面から得られた年代測定值と，推定される 断層活動時期との関係を Fig. 9 にまとめた. B トレンチ からは 4 層堆積後に最新活動（イベント 1）があったと 言え，その時期は年代測定值からは AD 1034 年以後と なり，11 世紀中葉以降と推定される。なお B トレンチ 壁面で断層を覆う地層は，崩積堆積物および人工改変を 受けた表土であり，最新活動時期の上限を限定すること はできない，A 地点の東方に位置する草野城址につい ては，少なくとも現状の遺構に断層変位が及んでいない 可能性が高いが, 草野城の詳細な成立時期や，放棄され た時期は不明である。

A1 トレンチからは, 3a 層堆積後, 2 層堆積前に, 少な くとも一部の副断層の活動があったと推定される。A1 トレンチの 2 層および $3 \mathrm{a}$ 層から得られた年代值は一部 で逆転する。これらの地層は腐植質土䁃で, 堆積後の再 移動や生物擾乱を受けている可能性も十分にあることか ら，年代測定值は地層の堆積年代としては誤差が大きい ものと考えられる。したがって，これらの副断層の活動 時期は，年代測定值が地層の堆積年代を示しているとす れば概ね 3,000〜3,500 年前頃の可能性があると言える が，2 層が崩積土もしくは人為的に再移動させられた土 壤であった場合は, 活動時期は $3 \mathrm{a}$ 層堆積後（約 3,000 年 前）以降としか言えず，Bトレンチのイベント 1 と分離 できない。 なお，副断層の活動時期を 3,000 3,500 年前 頃に限定した場合, この活動は最新活動に先立つ活動 （イベント 2）となる.

一方，B トレンチの 5 層の KB-E-07 から得られた年代 值が地層の堆積年代を示すとすると, 約 4,500 年前以降 に最新活動に先行する断層活動があったと考えることが できる，B トレンチの 5 層からは約 12,000 年前の年代 值も複数の試料から得られており, 吉岡・他 (2011) では 最新活動によって断層沿いに挟み込まれた試料の可能性 もあるとしているが，もしこの活動を最新活動に先行す る活動とすれば，A1 トレンチで推定されたイベント 2 はこの時期に含まれるため, 両者は同一の活動であった 可能性がある。なお, KB-E-07 が最新活動によって断層 沿いに挟み込まれた試料であった場合，このイベントは 


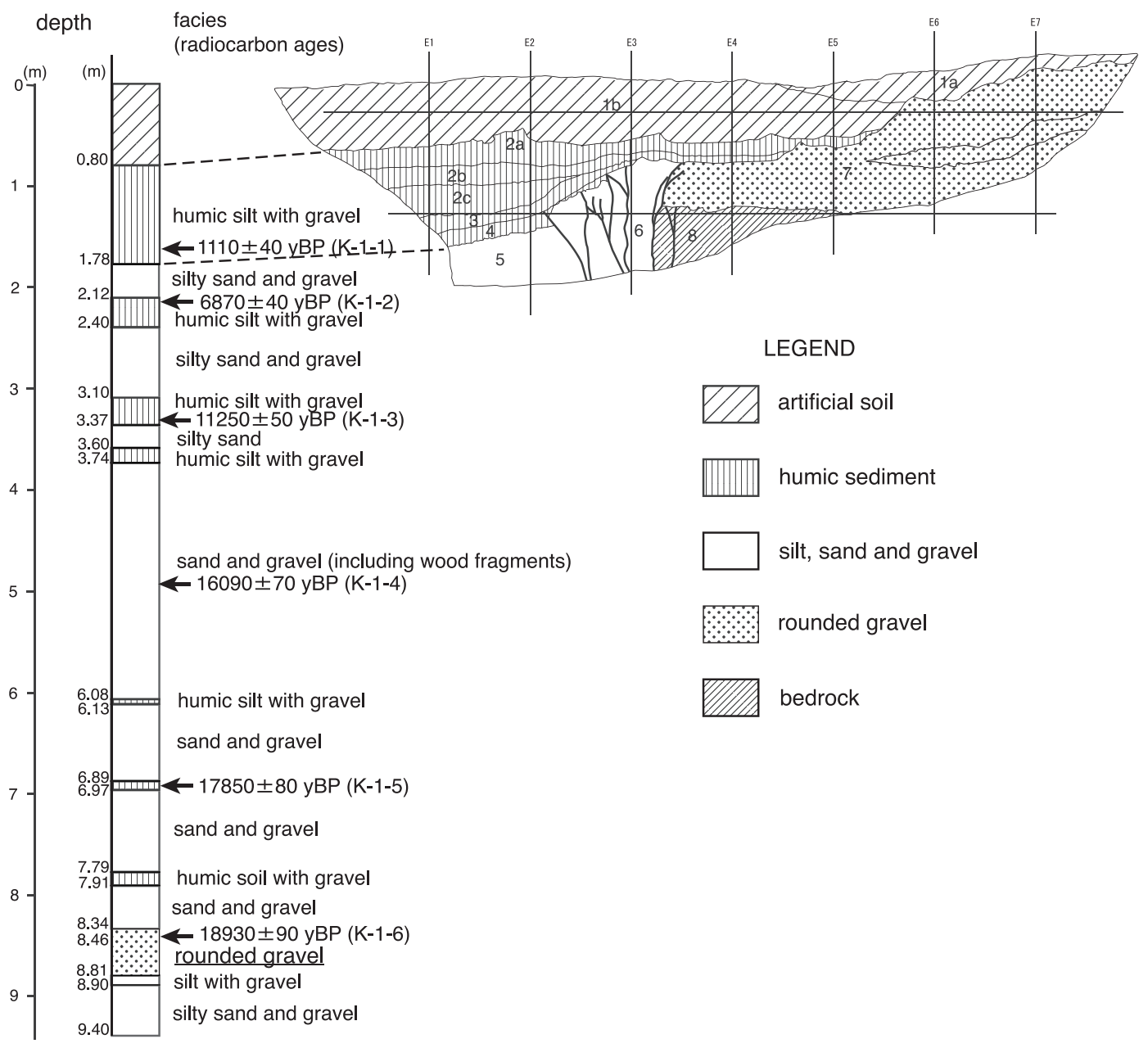

Fig. 8. Cross section of the Kajiya B trench wall and borehole.

後述するイベント 3 と分離できない.

さらに過去の活動としては, A1 トレンチの $3 \mathrm{~d}$ 層を断 層活動に伴うイベント堆積物と考えた場合, 3c 層堆積 後, 3e 層堆積前に断層活動（イベント3）が推定される. その活動時期は $3 \mathrm{c}$ 層および $3 \mathrm{e}$ 層から得られた年代值か ら概ね 7,000 年前頃となる。

以上の活動時期を隣接する活断層の活動時期と比較す ると, 鍛治屋断層のイベント 1 の時期は柳ヶ瀬断層の椿 坂地点で認められた西暦 1200 年代後半〜 1400 年代初頭 の活動 [杉山・他 (1993)］と，イベント 3 の時期は柳ヶ瀬 断層の椿坂峠トレンチ [吉岡・他 (1998)］での最新活動 時期（約 7,000〜 7,200 年前）と重なる。 またイベント 1 の時期は，養老断層や桑名断層の最新活動時期（それぞ れ 14 世紀以降，13 世紀以降）とも重なっている。鍛治 屋断層は地表での長さは約 $11 \mathrm{~km}$ と短いことから, 過去 の活動においては，近接する断層と連動して活動した可 能性が示唆される。

調査地点での鍛治屋断層の活動間隔は, イベント 1 か
ら 3 までを平均すると概ね 3,000 年程度となるが, イベ ント 2 がイベント 1 またはイベント 3 と同一であった場 合は，概ね 6,000 年程度となる。この值は，養老断層の 完新世における平均的な活動間隔（約 1,500 年）[須貝・ 他 (1999)］と比較して, 有意に長い. なお, 柳ヶ瀬断層 の活動間隔は正確に求められていないが, 椿坂峠トレン チでの最新活動時期が約 7,000〜 7,200 年前であることを 考慮すると，椿坂峠地点を含む区間の活動間隔は 7,000 年以上であることが推定される，以上のように，柳ヶ瀬 一養老断層系の活動間隔は，区間により大きく異なって いる。このことは，断層系を構成する複数断層が連動し て活動したとしても, その範囲は毎回同じとは限らない ことを意味している。

\section{2 平均変位速度の推定}

B 地点におけるボーリング調査の結果から, ボーリン グコア最下部の円礫層とトレンチ壁面の 7 層を対比する と, 約 22,000-23,000 年間に約 7-9 m の上下変位があっ たことになり (Fig. 8), その場合の上下方向の平均変位 


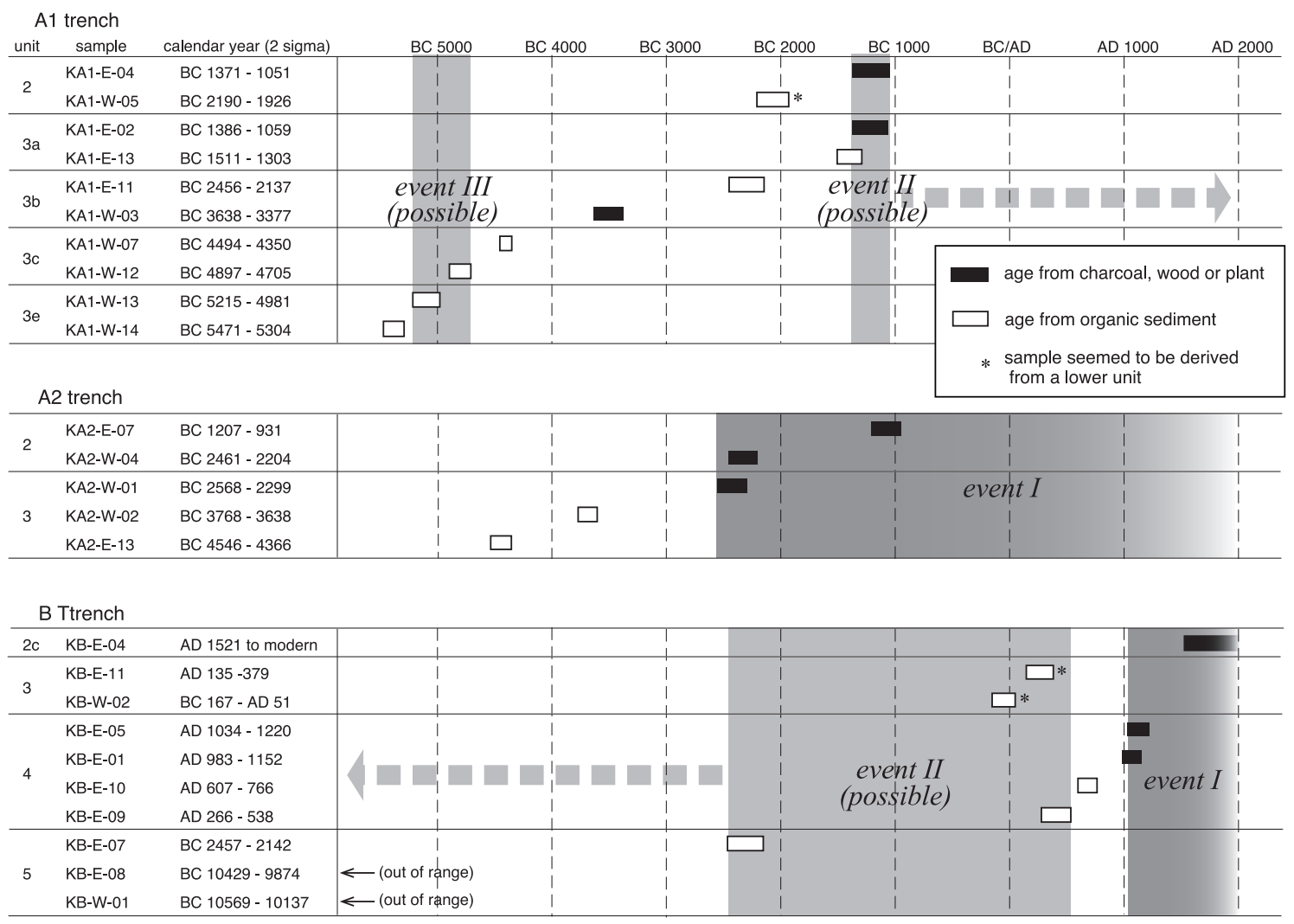

Fig. 9. Diagram showing radiocarbon ages from each trench and timings of estimated faulting events.

速度は約 0.3-0.4 m/千年と計算される。なお，鍛治屋断 層は地形から左横ずれ変位が卓越すると推定されている [活断層研究会編 (1991), 岡田・東郷編 (2000) など］こと から，この上下変位は横ずれによる谷の出口の堰き止め による見かけのものの可能性があるが，B 地点付近には その谷に相当する上流側の地形が見当たらないため, そ の可能性は低い.

B 地点を横切る地形断面図を Fig. 10 に示す。この図 によれば，断層低下側の堆積物の基底の高度は，草野川 沿いの沖積面とほぼ同レベルかそれ以下と推定され，完 新世における浸食基準面の低下を考えると，この地点で は断層の北東側が南西側に対して相対的に沈降している ことが示唆される．断層周辺の山地高度や段丘面の分布 には，断層の北東側が相対的に沈降するような傾向は見 られないため, 調査地点周辺における上下変位は局所的 なものである可能性が高いと考えられる。Aトレンチ 付近で，断層トレースが緩やかに左ステップ屈曲するの が認められる (Fig. 2). 調査地点における北東側低下の 上下変位は，左ステップ屈曲する断層が左横ずれ運動を 行うことに起因するプルアパート構造によるものと考え られる。

横ずれの平均変位速度については，年代を特定できる 変位基準がないため，直接求めることはできない，しか
しながら，例えば 1999 年トルコ，イズミット（コジャエ リ）地震に伴う地震断層では，3～ $5 \mathrm{~m}$ の横ずれ変位に対 して生じた複数のプルアパート構造の上下変位量が数十 $\mathrm{cm}$ ないし最大 $2 \mathrm{~m}$ 程度であったこと [Barka et al. (2002)] など，一般的にプルアパート構造の沈降量は，横ずれ変 位量と概ね同程度かそれ以下である。それに従えば，こ の地点の平均横ずれ変位速度は上下变位速度と概ね同程 度か，もしくはそれ以上であることが示唆される。

なお， $\mathrm{A}$ 地点の低断層崖の比高 $(1.5-2 \mathrm{~m})$ と段丘面の 年代 (50-70 ka と推定) からは, 0.02-0.04 m/千年の平均 上下変位速度が求められるが, 断層低下側の段丘堆積物 は上位の堆積物に覆われてトレンチ壁面には露出してい ないことから, 段丘面の真の変位量はこの崖の比高より もかなり大きいものと推定される。

\section{3 歴史地震との対応}

トレンチ調査の結果，鍛治屋断層の最新活動時期は概 ね 11 世紀の中葉以降であったものと推定された，B 卜 レンチの 2 層は断層変位で生じた窪みを人為的に埋めた 地層の可能性があり, 最新活動の発生直後には, すでに この地点で人間による土地造成が行われていたことが示 唆される. 調査地点の鍛治屋集落は, 室町時代に大和国 宇陀郡から鍛治職人が移住して繁栄し, 戦国時代には 「草野槍」として知られる多くの槍を作っており[長浜市 


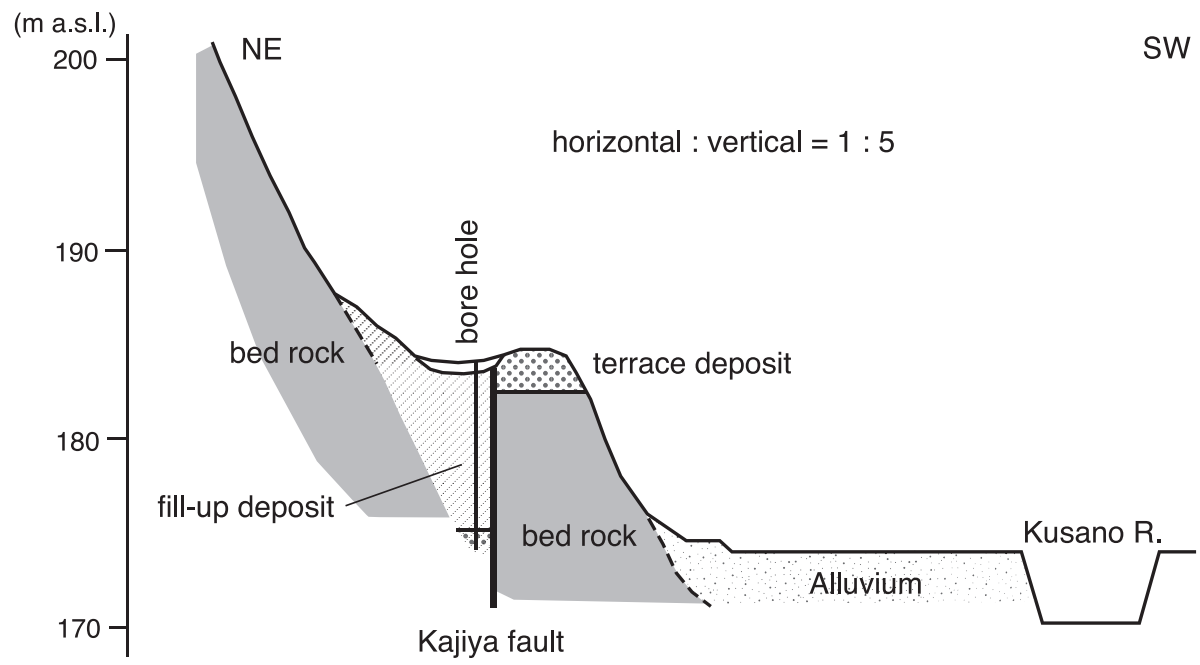

Fig. 10. Topographic cross section across the Kajiya B site.

史編纂委員会編 (2001)]，このことも断層の最新活動時 期が中世以降であったことと矛盾しない.

本地域周辺に大きな被害をもたらした歴史地震のうち 中世以降に発生したものとしては, 以下の地震が挙げら れる。 まず, 1325 年正中地震 $(M=6.5 \pm 1 / 4)$ では, 竹生 島や湖北山地の一部が崩壊するとともに，敦賀市の気比 神宮が倒壊したと伝えられている [宇佐美・他 (2013), 古代中世地震史料研究会 (2014)]。また, 1586 年天正地 震 $(M=7.8 \pm 0.1)$ では, 長浜城が倒壊し, 城主山内一豊の 娘が死亡したとされている [宇佐美・他 (2013), 古代中 世地震史料研究会 (2014)]. 1819 年文政近江地震 $(M=7$ $1 / 4 \pm 1 / 4)$ では, 滋賀県湖東地域を中心とする広い範囲 に被害があった。さらに，1909 年江濃（姉川）地震 (M =6.8) では，鍛治屋断層南側の平野部に被害が集中し, いくつかの集落で家屋の倒壊率が 50 パーセントを上 回った [宇佐美・他 (2013)]。これらのうち 1909 年江濃 （姉川）地震については, トレンチ地点には少なくとも明 治初期には民家が建てられ人が居住していた（地元の人 の話による）にもかかわらず，大きな被害が報告されて いないことから，この地震で鍛治屋断層が活動したとい うことは考えにくい. 1819 年文政近江地震については, 被害の分布などからフィリピン海プレートのスラブ内で 発生した地震との説もある [石橋 (1999)]。1586 年天正 地震では，養老断層が活動した可能性が指摘されている が [須貝・他 (1998，1999)]，ほかにも庄川断層帯や阿寺 断層帯など複数の活断層が連鎖的に活動した可能性 [岡 田 (2011)］や，日付の異なる複数の地震からなる可能性 [松浦 (2011)］が指摘されており，この地震の際に鍛治屋 断層が活動した可能性も否定できない。一方, 1325 年正 中地震については，鍛治屋断層の北西に連続する柳ヶ瀬
断層のトレンチ調査で西暦 1200 年代後半〜 1400 年代初 頭の活動が推定され, 1325 年正中地震の際に活動した可 能性が指摘されている [杉山・他 (1993)]。 よって, この 地震の際に, 鍛治屋断層も同時に活動したことも十分に 考えられる。しかしながら, ここに挙げた以外の地震の 際に活動した可能性も否定できないため, ここでは可能 性の 1 つとして指摘するにとどめる.

\section{§5. まと め}

鍛治屋断層の最新活動時期は, トレンチ調査の結果か ら 11 世紀後半以降と考えられる。対応する可能性があ る歴史地震としては 1325 年正中地震や 1586 年天正地震 が挙げられるが, 特定はできない. 最新活動に先行する 活動は，信頼性はやや劣るが概ね 3,000～3,500 年前頃お よび 7,000 年前頃にあった可能性があり, 後者は柳ヶ瀬 断層の椿坂峠トレンチ地点での最新活動時期と重なる.

調査地点での平均変位速度は上下方向で約 0.3-0.4 m/ 千年と見積もられるが, この值はプルアパート構造に伴 う局所的な変位速度の可能性がある。横ずれ変位速度は それと同程度もしくはそれ以上であることが示唆され る

\section{謝辞}

本研究を行うにあたり, 文部科学省研究開発局地震・ 防災研究課, 滋賀県防災危機管理局, 長浜市総務課防災 危機管理室, および調査地地権者をはじめとする地元関 係者の方々に多大なるご協力をいただいた．また松浦律 子博士, 堤 浩之博士および匿名査読者の貴重なご指摘 により，本稿は大幅に改善された。ここに記して感謝の 意を表する。 


\section{文献}

Barka, A., H. S. Akyuz, E. Altunel, G. Sunal, Z. Cakir, A. Dikbas, B. Yerli, R. Armijo, B. Meyer, J. B. de Chabelier, T. Rockwell, J. R. Dolan, R. Hartleb, T. Dawson, S. Christofferson, A. Tucker, T. Fumal, R. Langridge, H. Stenner, W. Lettis, J. Bachhuber, and W. Page, 2002, The surface rupture and slip distribution of the 17 August 1999 Izmit earthquake (M 7.4), North Anatolian fault, Bull. Seism. Soc. Amer., 92, 43-60.

Bronk Ramsey, C., 2001, Development of the radiocarbon calibration program OxCal, Radiocarbon, 43, 355-363.

Bronk Ramsey, C. and S. Lee, 2013, Recent and planned development of the program OxCal, Radiocarbon, 55, 720-730.

石橋克彦，1999，フィリピン海スラブ内で発生した 1819 (文政二) 年近江地震, 地球惑星科学関連学会 1999 年 合同大会予稿集，As-005.

石村大輔, 2010, 関ヶ原周辺における段丘編年と活断層 の活動性，第四紀研究，49，255-270.

活断層研究会編, 1991, 新編日本の活断層一分布図と資 料, 東京大学出版会, 437pp.

古代中世地震史料研究会, 2014, [古代・中世] 地震 - 噴 火史料データベース ( $\beta$ 版), 静岡大学防災総合セン ター, <http://sakuya.ed.shizuoka.ac.jp/erice/db/>, (参照 2015-6-16)

松浦律子, 2011, 天正地震の震源域特定: 史料情報の詳細 検討による最新成果, 活断層研究, no. 35, 29-39.

長浜市史編纂委員会編, 2001, 長浜市史 第 5 巻 暮し と生業, 長浜市役所, 467pp.

岡田篤正, 2011, 天正地震とこれを引き起こした活断層, 活断層研究, no. 35, 1-13.

岡田篤正・東郷正美編, 2000, 近畿の活構造, 東京大学 出版会, 408pp.

Reimer, P. J., E. Bard, A. Bayliss, J. W. Beck, P. G.
Blackwell, C. Bronk Ramsey, C. E. Buck, H. Cheng, R. R. Edwards, M. Friedrich, P. M. Grootes, T. P. Guilderson, H. Haflidason, I. Hajdas, C. Hatté, T. J. Heaton, D. L. Hoffmann, A. G. Hogg, K. A. Hughen, K. F. Kaiser, B. Kromer, S. W. Manning, M. Niu, R. W. Reimer, D. A. Richards, E. M. Scott, J. R. Southon, R. A. Staff, C. S. M. Turney, and J. van der Plicht, 2013, IntCal13 and Marine13 radiocarbon age calibration curve 0-50,000 years cal BP, Radiocarbon, 55, 1869-1887.

須貝俊彦・粟田泰夫 一下川浩一, 1998, 桑名断層・四日 市断層の活動履歴調査, 地質調査所速報, EQ/98/1, 75-90.

須貝俊彦・伏島祐一郎・粟田泰夫 - 吾妻 崇・苅谷愛彦・ 鈴木康弘， 1999，養老断層の完新世後期の活動履歴一 1596 年天正地震 ・ 745 年天平地震震源断層の可能性, 地質調査所速報, EQ/99/3, 89-102.

杉山雄一 - 粟田泰夫 ・佃 栄吉 - 吉岡敏和, 1993, 1992 年柳ヶ瀬断層（椿坂地区）トレンチ調査, 活断層研究, no. 11, 100-109.

杉山雄一・粟田泰夫 - 吉岡敏和, 1994, 柳ヶ瀬-養老断層 系ストリップマップ, 構造図 10, 地質調査所, 1 sheet. 東郷正美 - 岡田篤正 - 澤祥 - 鈴木康弘 - 堤 浩之 ・ 平川一臣, 2005, 1:25,000 都市圈活断層図「長浜」, 国 土地理院技術資料 D・1-No. 449 .

宇佐美龍夫 - 石井 寿 -今村隆正 - 武村雅之 ・松浦律子, 2013, 日本被害地震総覧 599-2012, 東京大学出版会, $694 \mathrm{pp}$

吉岡敏和・杉山雄一・細矢卓志・逸見健一郎・渡辺俊一・ 田中英幸, 1998, 柳ヶ瀬断層の最新活動一滋賀県余吳 町椿坂峠におけるトレンチ発掘調査一, 地震 $2, \mathbf{5 1}$, 281-289.

吉岡敏和・佐護浩一・山根 博, 2011, 柳ヶ瀬-養老断層 系, 鍛治屋. 関ヶ原, 宮代断層の古地震調査, 活断層 古地震研究報告, no. 11, 177-195. 